saying it will help to preserve public confidence and allow scientists to learn from the incident, "I'm sure it will introduce a note of caution in every experimentalist who does gene therapy, and that's a good thing," he says.

Verma describes vectors as the "Achilles heel" of gene therapy, and says that doseescalation studies using adenoviruses should be re-examined. Most gene therapy involves retroviral vectors, but adenoviruses are popular for cancer and cystic fibrosis.

Verma says he thinks vectors like the one used in the OTC trial will soon be abandoned in favour of 'gutless' adenoviruses, retroviruses, AAV or lentivectors.

A major problem of adenoviruses is that even inactivated versions can stimulate an immune response. Sustained expression of the gene is therefore impossible, and the immune system may destroy infected cells - the very cells targeted for help. The severe inflammation associated with these vectors, especially in the liver, is particularly dangerous for OTC patients.

Members of the NIH's Recombinant DNA Advisory Committee (RAC), which at

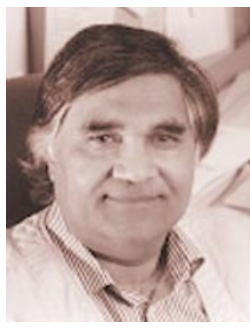

Verma: new caution is "a good thing". the time held regulatory authority over gene therapy experiments using federal funds, approved the protocol 11 to one, with four abstentions. They raised concerns about the risks of the treatment and its use — for the first time in gene therapy - in asymptomatic patients.

Individuals without the targeted gene cannot break down nitrogen, which can lead to a fatal build-up of ammonia soon after birth. The gene is X-linked - female carriers usually lead normal lives, but up to ten per cent of them could experience dangerous symptoms. Patients with partial enzyme production have done well under dietary and drug treatment.

The investigators had studied their vector in mice and primates. In the December 1995 review of the proposal for a trial in humans, RAC members discussed the potential for lethal liver inflammation based on toxicity results in Rhesus monkeys and one animal's death after an extremely high dose of a first-generation vector.

The likelihood of efficacy and the importance for this and other liver conditions convinced them to approve the study, with the recommendation that the researchers use a less invasive route of administration through a peripheral vein.

Because of concerns about infection of reproductive cells, FDA regulators made the researchers go back to treating the liver directly. Under current rules, such an experiment might be reviewed by the RAC, but only requires approval from the FDA. An FDA spokesman said that the agency cannot discuss experiments or their results without the consent of the investigators concerned.

Verma and others point to the technology's success in thousands of patients up to now, and say that the death should not be seen as a setback for gene therapy as a whole. "We would obviously prefer that this tragedy had not happened," says Wivel. "But these things do occur in cutting-edge research."

Sally Lehrman

\title{
Ig prizes spawn a new generation of Nobels
}

Boston

Heredity was the theme of the 'Ninth First Annual' Ig Nobel Prize ceremony at Harvard University last week, where the King and Queen of Swedish Meatballs presided as usual over the festivities.

Beach-balls, paper aeroplanes and giant doughnuts sailed through the air of a Harvard University auditorium, while Lawyers For and Against Heredity carried placards and a group of female physics students called Babes in Boyland marched in procession. In keeping with the heredity motif, descendants of famous scientists, including Francis Crick's granddaughter, took the stage.

The world premier of The Seedy Opera, a tribute to scientist and entrepreneur Richard Seed (winner of the Ig Nobel Prize for Economics in 1998), who has vowed to clone himself and other humans, was presented in four acts. Four Harvard Nobel laureates Sheldon Glashow, Robert Wilson, Dudley Herschbach and William Lipscomb played the parts of cloned sheep in the opera.

This year, Ig Nobel prizes were awarded in ten categories for work that either "cannot or should not be reproduced". Recipients came from as far afield as Australia, Japan, Norway and the United States to collect the coveted Ig prize, which resembles a plaster frog.

The science-education prize was issued jointly to the Kansas and Colorado boards of education for mandating that "children should not believe in Darwin's theory of evo-

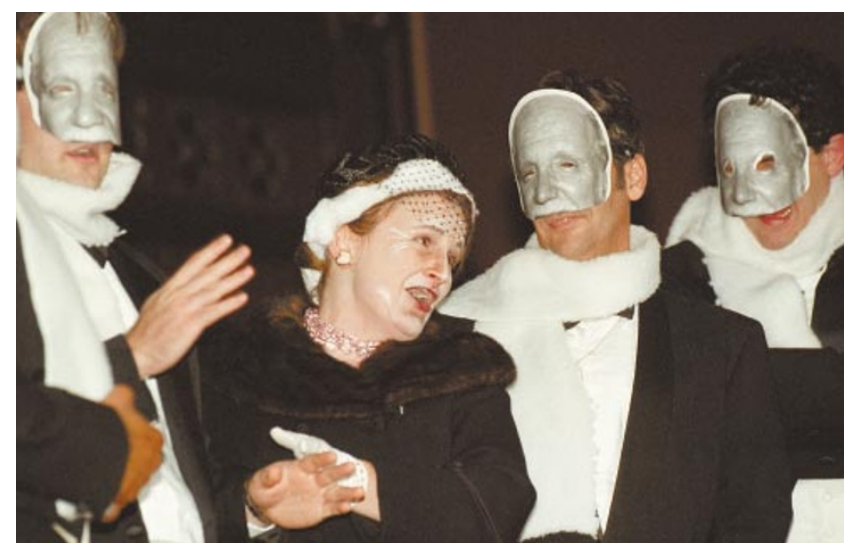

Cloning around: the world premier of The Seedy Opera, a tribute to one of last year's winners, Richard Seed, the Chicagobased former physicist who has vowed to clone himself and others.

lution, any more than they believe in Newton's theory of gravitation, Faraday's and Maxwell's theory of electromagnetism, or Pasteur's theory that germs cause disease".

Commenting on the award, University of Kansas biologist Douglas Ruden warned other states "not to let what happened in Kansas happen to you. As Dan Quayle said: 'A mind is a terrible thing to lose."'

Len Fisher of England and Australia captured one of two physics prizes, for calculating the optimal way to dunk a biscuit (see Nature 397, 469; 1999). The other award went to Jean-Marc Vanden-Broeck of the University of East Anglia for calculating how to make a teapot spout that does not drip.

Norway's Arvid Vatle earned the prize for medicine for an analysis of the containers chosen by patients for urine samples. The late
George and Charlotte Blonsky were posthumously awarded the managed health care prize for inventing a high-speed rotary chair for women in labour, to accelerate the birth process. "As chair of preventive medicine at Brigham and Women's Hospital, it's my job to prevent this kind of medicine," said JoAnn Manson of Harvard Medical School.

Takeshi Makino of Japan won the chemistry prize for developing an infidelity-detection spray for wives to apply to their husbands' underwear. The peace prize went to South Africa's Charl Fourie and Michelle Wong for inventing a car burglar alarm that comes equipped with a flame-thrower "These achievements speak for themselves," claimed master of ceremonies Marc Abrahams, editor of the science humour magazine Annals of Improbable Research. Steve Nadis 